\title{
Edwardsiella ictaluri sp. nov., the Causative Agent of Enteric Septicemia of Catfish
}

\author{
JOHN P. HAWKE, $†$ ALMA C. McWHORTER, $\ddagger$ ARNOLD G. STEIGERWALT, $\ddagger$ AND \\ DON J. BRENNER $\ddagger$ \\ Department of Fisheries and Allied Aquacultures, Auburn University, Auburn, Alabama 36849
}

We characterized 13 cultures of the enteric bacterium causing enteric septicemia of catfish by studying their biochemical reactions, deoxyribonucleic hybridizations, and deoxyribonucleic acid guanine-plus-cytosine contents. We confirmed that this bacterium is a new species, which is most closely related to Edwardsiella tarda of the family Enterobacteriaceae. Five strains of the bacterium causing enteric septicemia of catfish were $80 \%$ or more related to the type strain, SECFDL GA 77-52 (= CDC 1976-78 = ATCC 33202), in $60^{\circ} \mathrm{C}$ deoxyribonucleic acid homology reactions. Species level relatedness among the 13 strains which we studied was demonstrated by the more than $80 \%$ relatedness in $75^{\circ} \mathrm{C}$ reactions. The bacterium causing enteric septicemia of catfish was most closely related to $E$. tarda (56 to $62 \%$ ) in $60^{\circ} \mathrm{C}$ reactions. The guanine-plus-cytosine was $53 \mathrm{~mol} \%$, as determined by buoyant density centrifugation. We propose the name Edwardsiella ictaluri sp. nov. for the bacterium causing enteric septicemia of catfish.

Enteric septicemia of catfish (ESC) is a newly described bacterial disease primarily of cultured channel catfish (Ictalurus punctatus) (9). The causative agent of this disease is a gram-negative, rod-shaped, 0.5 - by $1.25-\mu \mathrm{m}$, oxidase-negative, peritrichous, fermentative bacterium that has been isolated 26 different times from the kidney tissues of moribund catfish. Biochemically, this organism is most similar to Edwardsiella tarda but differs from $E$. tarda in several key diagnostic characteristics (1).

ESC was first detected in 1976. Although not always consistent, the clinical signs of this disease in $I$. punctatus are typical of the acute bacterial septicemias caused by $E$. tarda, Aeromonas hydrophila, and Pseudomonas fluorescens $(5,11)$.

ESC presently constitutes an economic threat to catfish farmers in Alabama, Georgia, and Mississippi. The pathogenicity of the ESC bacterium to species of fish other than catfish has not been demonstrated, although it has been isolated from channel catfish (I. punctatus), white catfish (Ictalurus catus), and brown bullhead (Ictalurus nebulosus). In this paper we characterize, classify, and name the ESC bacterium.

\section{MATERIALS AND METHODS}

Bacterial strains. Since the initial isolation of the ESC bacterium in July 1976, a total of 24 strains has

† Present address: Alabama Department of Conservation and Natural Resources, Marine Resources Division, Gulf Shores, AL 36542.

$\ddagger$ Present address: Enteric Section, Centers for Disease Control, Atlanta, GA 30333. been isolated from diseased fish in Alabama and Georgia by the Southeastern Cooperative Fish Disease Laboratory, Auburn University. Two additional isolates were received by the Southeastern Cooperative Fish Disease Laboratory from Maryland and Mississippi for identification in 1978 . These 26 cultures represented approximately $12 \%$ of all reports of fish diseases of bacterial etiology recorded from January 1976 to October 1979 at the Southeastern Cooperative Fish Disease Laboratory. We used 13 of these strains in this study (Table 1).

Methods. Cellular morphology was determined by Gram staining and flagellation was determined by using the modified Leifson stain (Becton, Dickenson $\&$ Co.). Motility was determined in wet mounts with

TABLE 1. Sources of the strains on which the description of the ESC bacterium is based

\begin{tabular}{|c|c|c|c|}
\hline $\begin{array}{l}\text { Centers } \\
\text { for Dis- } \\
\text { ease } \\
\text { Control } \\
\text { no. }\end{array}$ & SECFDL $^{a}$ no. & Source & $\begin{array}{c}\text { Geographic } \\
\text { origin }\end{array}$ \\
\hline $1975-78$ & GA $\quad 78-27$ & Channel catfish & Georgia \\
\hline $1976-78$ & GA $\quad 77-52$ & Channel catfish & Georgia \\
\hline $1977-78$ & AL $\quad 78-118$ & Channel catfish & Alabama \\
\hline $2917-78$ & GA $78-33$ & Channel catfish & Georgia \\
\hline 2918-78 & AL $\quad 78-119$ & Channel catfish & Alabama \\
\hline $2919-78$ & AL $\quad 78-120$ & Channel catfish & Alabama \\
\hline $2920-78$ & AL $\quad 78-123$ & Channel catfish & Alabama \\
\hline $2921-78$ & AL $\quad 78-125$ & Channel catfish & Alabama \\
\hline $2922-78$ & AL $\quad 78-126$ & Channel catfish & Alabama \\
\hline 2923-78 & AL $\quad 78-145$ & Channel catfish & Alabama \\
\hline $2924-78$ & GA $78-36$ & Channel catfish & Georgia \\
\hline $2925-78$ & MD $78-1$ & White catfish & Maryland \\
\hline 2926-78 & MS $78-1$ & Channel catfish & Mississippi \\
\hline
\end{tabular}

${ }^{a}$ SECFDL, Southeastern Cooperative Fish Disease Laboratory. 
phase-contrast microscopy and in semisolid glucose motility deep cultures (16). The optimum growth temperature for each isolate was determined by inoculat- ing glucose motility deep cultures by vertical stabbing with a needle and incubating these cultures for $96 \mathrm{~h}$ at $4,10,12,15,20,25,30,35,37$, and $40^{\circ} \mathrm{C}$. The temper-

TABLE 2. Biochemical characteristics of 13 strains of E. ictaluri sp. nov.

\begin{tabular}{|c|c|c|}
\hline Characteristic & Reaction of type strain (GA $77-52)^{\circ}$ & $\begin{array}{l}\text { No. of strains giving } \\
\text { opposite reaction }\end{array}$ \\
\hline Gram strain .... & - & 0 \\
\hline 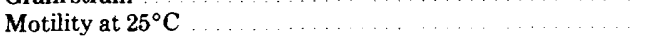 & + & $1^{b}$ \\
\hline$\ldots \ldots \ldots \ldots$ & - & 0 \\
\hline Flagellation $\ldots \ldots \ldots \ldots \ldots \ldots$ & $+($ Peritrichous $)$ & 0 \\
\hline 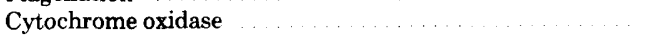 & - & 0 \\
\hline Nitrate reduction to nitrite & + & 0 \\
\hline $\mathrm{O} / \mathrm{F}$ test $\left(25^{\circ} \mathrm{C}\right)$ & $+/+^{c}$ & 0 \\
\hline Pigment & - & 0 \\
\hline$o$-Nitrophenyl- $\beta$-D-galactopyranoside $\ldots \ldots \ldots \ldots \ldots$ & $(+)$ & 0 \\
\hline $\mathrm{H}_{2} \mathrm{~S}$ (from triple sugar iron agar) $\ldots \ldots \ldots \ldots$ & - & 0 \\
\hline 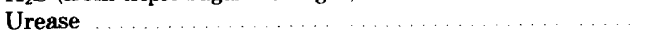 & - & 0 \\
\hline Indole & - & 0 \\
\hline$\ldots \ldots \ldots \ldots \ldots \ldots \ldots \ldots \ldots \ldots \ldots \ldots \ldots \ldots$ & $(+)$ & $4^{d}$ \\
\hline Voges-Proskauer $\ldots \ldots \ldots \ldots$ & - & 0 \\
\hline Citrate (Simmons) $\ldots \ldots \ldots \ldots$ & - & 0 \\
\hline$\ldots \ldots \ldots \ldots \ldots \ldots \ldots \ldots$ & - & 0 \\
\hline Gelatin $\left(22^{\circ} \mathrm{C}\right)$ & - & 0 \\
\hline Arginine dihydrolase $\ldots \ldots \ldots \ldots \ldots \ldots \ldots \ldots$ & - & 0 \\
\hline Lysine decarboxylase $\ldots \ldots \ldots \ldots \ldots$ & + & 0 \\
\hline Ornithine decarboxylase $\ldots \ldots \ldots \ldots \ldots \ldots$ & + & $7^{e}$ \\
\hline 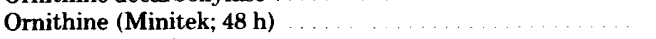 & - & 0 \\
\hline Phenylalanine deaminase $\ldots \ldots \ldots \ldots \ldots \ldots$ & - & 0 \\
\hline 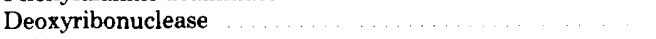 & - & 0 \\
\hline D-Glucose $\ldots \ldots \ldots \ldots \ldots \ldots$ & + & 0 \\
\hline 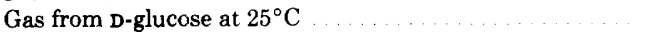 & + & 0 \\
\hline Gas from $\mathrm{D}$-glucose at $37^{\circ} \mathrm{C} \ldots \ldots \ldots \ldots$ & - & 0 \\
\hline Lactose $\ldots \ldots \ldots \ldots \ldots$ & - & 0 \\
\hline 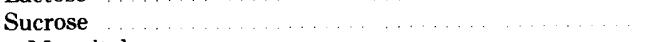 & - & 0 \\
\hline 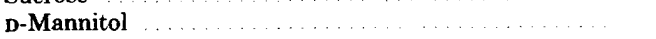 & - & 0 \\
\hline 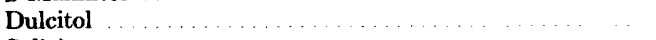 & - & 0 \\
\hline Salicin $\ldots \ldots \ldots \ldots \ldots \ldots \ldots \ldots$ & - & 0 \\
\hline 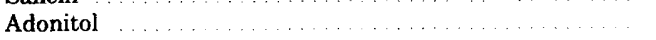 & - & 0 \\
\hline 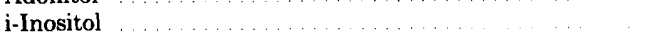 & - & 0 \\
\hline D-Sorbitol $\ldots \ldots \ldots \ldots \ldots \ldots$ & - & 0 \\
\hline 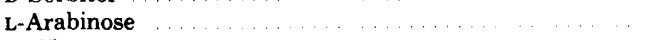 & - & 0 \\
\hline 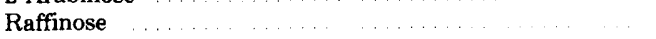 & - & 0 \\
\hline 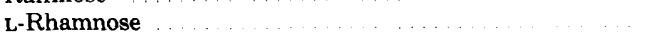 & - & 0 \\
\hline Malonate $\quad \ldots \ldots \ldots \ldots \ldots \ldots$ & - & 0 \\
\hline Maltose $\ldots \ldots \ldots \ldots$ & + & 0 \\
\hline 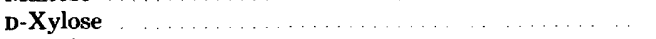 & - & 0 \\
\hline 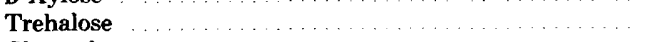 & - & 0 \\
\hline Glycerol $\ldots \ldots \ldots \ldots \ldots \ldots \ldots \ldots \ldots$ & $(+)$ & $2^{f}$ \\
\hline 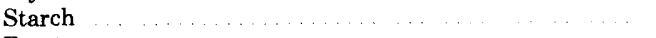 & - & 0 \\
\hline Fructose $\ldots \ldots \ldots \ldots$ & + & 0 \\
\hline Galactose $\ldots \ldots \ldots \ldots \ldots$ & + & 0 \\
\hline 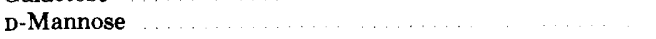 & + & 0 \\
\hline Sorbose $\ldots \ldots \ldots \ldots \ldots \ldots$ & - & 0 \\
\hline 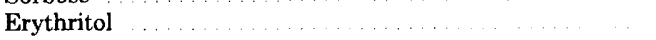 & - & 0 \\
\hline Ribose $\ldots \ldots \ldots \ldots \ldots \ldots \ldots \ldots$ & + & 0 \\
\hline 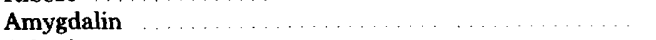 & - & 0 \\
\hline 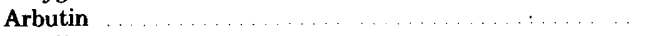 & - & 0 \\
\hline 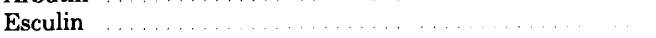 & - & 0 \\
\hline 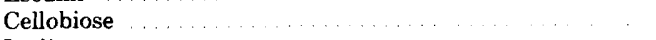 & - & 0 \\
\hline Inulin $\ldots \ldots \ldots \ldots$ & - & 0 \\
\hline 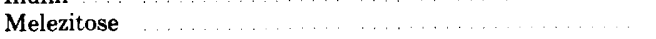 & - & 0 \\
\hline Dextrin $\ldots \ldots \ldots \ldots \ldots \ldots \ldots \ldots \ldots$ & - & 0 \\
\hline
\end{tabular}

${ }^{a}$ Symbols: + , Positive reaction within $48 \mathrm{~h} ;(+)$, positive reaction between 3 and 9 days; - , negative reaction after 7 days. The incubation time and temperature were $48 \mathrm{~h}$ and $37^{\circ} \mathrm{C}$, respectively, unless otherwise noted.

Strain MS 78-1.

'Acid produced oxidatively and fermentatively in Hugh and Leifson O/F medium.

d Strains GA 78-36, AL 78-120, AL 78-126, and MD 78-1.

e The following strains gave a delayed positive reaction after 2 to 3 days at $37^{\circ} \mathrm{C}$ : GA $78-33, \mathrm{AL} 78-119, \mathrm{AL} 78-125, \mathrm{AL} 78-120$, AL 78-123, AL 78-126, and MS 78-1.

${ }^{t}$ Strains GA 77-52 and GA 78-27. 
ature at which motility and acid production were most pronounced was considered to be optimum.

The antimicrobial agent susceptibility of each isolate was determined by the agar diffusion method (2), but we used sensitivity agar (Difco Laboratories) rather than Mueller-Hinton agar due to poor growth of the isolates on Mueller-Hinton agar.

Biochemical testing was done by the methods of Edwards and Ewing (6) and Hickman and Farmer (10). Additional testing was conducted by using the Analytab 20E system (Analytab Products) and the Minitek system (BBL Microbiology Systems).

Antisera for a serological comparison of the ESC strains and a stock culture of E. tarda obtained from the National Fish Health Center, Kearneysville, W. Va., were prepared in adult channel catfish by using heat-killed bacteria. The fish were bled at the conclusion of a 6-week injection schedule. Sera from each group were pooled and refrigerated at $4^{\circ} \mathrm{C}$. Control serum was obtained from preinjection bleedings. Slide agglutination tests were performed by using two-fold dilutions of antiserum mixed with an antigen suspension calibrated to a no. $10 \mathrm{McF}$ arland barium chloride standard.

The strains and techniques used to prepare and label deoxyribonucleic acids (DNAs) and to determine DNA relatedness have been described previously (3).

Determinations of guanine-plus-cytosine contents was by buoyant density centrifugation in cesium chloride (D. H. Lewis, personal communication).

\section{RESULTS AND DISCUSSION}

The ESC bacterium is a gram-negative rodshaped organism which measures 1.75 by $5.0 \mu \mathrm{m}$ after $6 \mathrm{~h}$ of culture on solid media and 0.5 by $1.25 \mu \mathrm{m}$ after 18 to $48 \mathrm{~h}$ of culture (A. Scott, personal communication). This organism is peritrichous; all strains tested except strain MS 781 were motile at $25^{\circ} \mathrm{C}$ but not at $37^{\circ} \mathrm{C}$; strain MS 78-1 was not motile at either temperature.

The biochemical reactions of the 13 strains of the ESC bacterium tested were almost identical (Table 2). The optimum growth temperature for the ESC bacterium was between 25 and $30^{\circ} \mathrm{C}$. Growth was slow on blood agar plates; at $30^{\circ} \mathrm{C}$ this organism took $48 \mathrm{~h}$ to form typical colonies $2 \mathrm{~mm}$ in diameter. All strains produced gas from glucose at $25^{\circ} \mathrm{C}$ but not at $37^{\circ} \mathrm{C}$, and all strains were negative for indole production and $\mathrm{H}_{2} \mathrm{~S}$ production from triple sugar iron agar. Six of the strains were positive for ornithine decarboxylase after $24 \mathrm{~h}$, four strains were positive after 3 days, and three strains were positive after 5 days of incubation at $37^{\circ} \mathrm{C}$.

The tests which differentiated the ESC bacterium from $E$. tarda were motility at $37^{\circ} \mathrm{C}$, the indole test, the Jordan tartrate test, gas production from glucose at $37^{\circ} \mathrm{C}$, and $\mathrm{H}_{2} \mathrm{~S}$ production from triple sugar iron agar; the ESC strains were negative for all of these characters $(4,7,13)$. The ESC bacterium was differentiated from Yersinia ruckeri (another enteric fish pathogen) by the delayed motility of the $\mathrm{ESC}$ bacterium at $25^{\circ} \mathrm{C}$, by gas production from glucose at $25^{\circ} \mathrm{C}$, and by negative tests for citrate utilization (Simmons), trehalose utilization, gelatin liquefaction $\left(22^{\circ} \mathrm{C}\right)$, and tartrate utilization (Jordan) $(8,12)$. The tests which have diagnostic significance for the ESC bacterium are shown in Table 3.

We detected no cross-agglutination in experiments with $E$. tarda antiserum and ESC bacterium antigen or with E. tarda antigen and ESC bacterium antiserum. A titer of 160 was obtained with E. tarda antigen and the homologous antiserum, and a titer of 320 was obtained with ESC bacterium antigen and the homologous antiserum.

The guanine-plus-cytosine content of the ESC bacterium DNA was $53 \mathrm{~mol} \%$, as determined by buoyant density centrifugation (Lewis, personal communication).

The antimicrobial agent susceptibility of the ESC bacterium has been reported previously (9); this bacterium is susceptible to oxytetracycline, chlortetracycline, kanamycin, neomycin, nitrofurazone, and dihydrostreptomycin and resistant to erythromycin and sulfamerizine.

Table 4 shows the DNA relatedness among the ESC strains and between the ESC bacterium and other members of the family Enterobacteriaceae. Five strains of the ESC bacterium were $80 \%$ or more related to strain 1976-78 (GA 77 $52)$ in $60^{\circ} \mathrm{C}$ reactions. There was no evidence of divergence within related sequences, as judged by the absence of decreased thermal stability within related DNA sequences. The species level relatedness among the ESC strains was evident from the more than $80 \%$ relatedness observed in the $75^{\circ} \mathrm{C}$ reactions, in which only very closely related DNA sequences could form duplexes.

TABLE 3. Biochemical and biophysical characteristics important in differentiating three fish pathogens belonging to the family Enterobacteriaceae

\begin{tabular}{lccc}
\hline \multirow{2}{*}{ Characteristic } & \multicolumn{3}{c}{ Reaction of: $^{a}$} \\
\cline { 2 - 4 } & E. ictaluri & E. tarda & Y. ruckeri \\
\hline Motility at $25^{\circ} \mathrm{C}$ & $(+)$ & + & + \\
Motility at $37^{\circ} \mathrm{C}$ & - & + & - \\
Indole & - & + & - \\
Citrate (Simmons) & - & - & + \\
Trehalose & - & - & + \\
Gelatin $\left(22^{\circ} \mathrm{C}\right)$ & - & - & + \\
Jordan tartrate & - & + & + \\
Gas from glucose at & + & + & - \\
$25^{\circ} \mathrm{C}$ & - & + & - \\
Gas from glucose at & - & + & - \\
$37^{\circ} \mathrm{C}$ & - & + & + \\
$\mathrm{H}_{2} \mathrm{~S}$ & & &
\end{tabular}

${ }^{a}+$, Positive reaction within $48 \mathrm{~h} ;(+)$, positive reaction between 3 and 7 days; -, negative reaction. The incubation time and temperature were $48 \mathrm{~h}$ and $37^{\circ} \mathrm{C}$, respectively, unless otherwise noted. 
TABLE 4. DNA relatedness of E. ictaluri strain GA 77-52 (=CDC 1976-78) to other members of the family Enterobacteriaceae

\begin{tabular}{|c|c|c|c|c|}
\hline \multicolumn{2}{|c|}{ Source of unlabeled DNA } & \multirow{2}{*}{$\begin{array}{l}\text { Relative binding } \\
\text { ratio at } 60^{\circ} \mathrm{C}^{a}\end{array}$} & \multirow{2}{*}{ \% Divergence ${ }^{h}$} & \multirow{2}{*}{$\begin{array}{l}\text { Relative binding } \\
\text { ratio at } 75^{\circ} \mathrm{C}^{\prime}\end{array}$} \\
\hline Species & Strain & & & \\
\hline E. ictaluri & $1976-78$ & 100 & 0.0 & 100 \\
\hline E. ictaluri & $2929-78$ & 97 & 0.0 & 98 \\
\hline E. ictaluri & $2921-78$ & 95 & 0.0 & 97 \\
\hline E. ictaluri & $2925-78$ & 84 & 0.0 & 84 \\
\hline E. ictaluri & $1977-78$ & 83 & 0.0 & 85 \\
\hline E. ictaluri & $2918-78$ & 81 & 0.0 & 84 \\
\hline E. tarda & $5497-61$ & 62 & 14.5 & 32 \\
\hline E. tarda & $3592-64$ & 61 & 12.0 & 28 \\
\hline E. tarda & $1126-64$ & 56 & 13.5 & 28 \\
\hline Escherichia coli & $\mathrm{K}-12$ & 31 & & 6 \\
\hline Shigella boydii .............. & $1610-55$ & 28 & & 5 \\
\hline Salmonella typhimurium & LT2 & 35 & & 11 \\
\hline Citrobacter freundii & $460-61$ & 33 & & 7 \\
\hline Citrobacter diversus $\ldots \ldots \ldots \ldots$ & $1066-71$ & 37 & & 8 \\
\hline Levinea amalonatica & 25406 & 34 & & 8 \\
\hline Klebsiella pneumoniae . . . . . & 2 & 24 & & 11 \\
\hline Klebsiella oxytoca & 13182 & 35 & & 6 \\
\hline Enterobacter aerogenes & $1627-66$ & 34 & & 9 \\
\hline Enterobacter cloacae & $1347-71$ & 33 & & 9 \\
\hline Enterobacter sakazakii & $4562-70$ & 29 & & 5 \\
\hline Enterobacter gergoviae & $604-77$ & 32 & & 12 \\
\hline Enterobacter agglomerans & $2780-70$ & 34 & & 9 \\
\hline Enterobacter agglomerans & $3123-80$ & 24 & & 14 \\
\hline Enterobacter agglomerans & $1429-71$ & 28 & & 12 \\
\hline Enterobacter agglomerans & $1741-71$ & 32 & & 8 \\
\hline Enterobacter agglomerans $\ldots$. & $3482-71$ & 28 & & 8 \\
\hline Enterobacter agglomerans & $6070-69$ & 27 & & 5 \\
\hline Enterobacter agglomerans & $6003-71$ & 18 & & 9 \\
\hline Enterobacter agglomerans & $5422-69$ & 30 & & 11 \\
\hline Enterobacter agglomerans & $4388-71$ & 41 & & 9 \\
\hline Enterobacter agglomerans & $1600-71$ & 25 & & 6 \\
\hline Enterobacter agglomerans & $5378-71$ & 37 & & 10 \\
\hline Enterobacter agglomerans & $219-71$ & 40 & & 8 \\
\hline Enterobacter agglomerans & $1645-71$ & 30 & & 6 \\
\hline Erwinia amylovora & EA 178 & 30 & & 8 \\
\hline Erwinia nigrifluens & EN 104 & 30 & & 12 \\
\hline Erwinia quercina & EQ 102 & 24 & & 8 \\
\hline Erwinia rubrifaciens & ER 105 & 17 & & 7 \\
\hline Erwinia salicis . . . . . & ES 102 & 25 & & 8 \\
\hline Erwinia carotovora & 495 & 33 & & 12 \\
\hline Erwinia carnegieana & EC 186 & 25 & & 7 \\
\hline Erwinia chrysanthemi & SR 32 & 15 & & 8 \\
\hline Erwinia cypripedii & EC 155 & 32 & & 9 \\
\hline Erwinia rhapontici & ER 106 & 30 & & 8 \\
\hline Erwinia mallotivora $\ldots \ldots \ldots \ldots$ & 2851 & 30 & & 10 \\
\hline Serratia marcescens ............ & $868-57$ & 30 & & 12 \\
\hline Serratia liquefaciens $\ldots \ldots \ldots$ & $446-68$ & 31 & & 7 \\
\hline Serratia rubidaea ............ & $934-72$ & 31 & & 12 \\
\hline Serratia fonticola & $4556-71$ & 33 & & 8 \\
\hline Serratia plymuthica . . . . . . & 392 & 34 & & 13 \\
\hline Hafnia alvei $\ldots \ldots \ldots \ldots \ldots$ & $5632-72$ & 30 & & 7 \\
\hline Proteus mirabilis . . . . . . . . & PR 14 & 8 & & 2 \\
\hline Proteus vulgaris & PR 1 & 6 & & 1 \\
\hline Proteus myxofaciens & 19692 & 7 & & 2 \\
\hline Providencia alcalifaciens . . . . . & $3370-67$ & 11 & & 3 \\
\hline Providencia alcalifaciens . . . . & 26240 & 10 & & 1 \\
\hline Providencia stuartii $\ldots \ldots \ldots$ & $2896-68$ & 8 & & 0 \\
\hline Providencia rettgeri $\ldots \ldots \ldots$ & 1163 & 10 & & 2 \\
\hline Morganella morganii & 25830 & 24 & & 8 \\
\hline Yersinia enterocolitica . . . . . . & $497-70$ & 26 & & 2 \\
\hline Yersinia pseudotuberculosis .... & P 62 & 18 & & 7 \\
\hline
\end{tabular}


TABLE 4-Continued

${ }^{a}$ Relative binding ratio $=[$ (percentage of heterologous DNA bound to hydroxyapatite $) /($ percentage of homologous DNA bound to hydroxyapatite $)] \times 100$.

${ }^{b}$ The percent divergence was the decrease in thermal stability of heterologous DNA duplexes compared with the thermal stability of the homologous DNA duplexes. This value could be expressed as a percentage because each degree decrease in thermal stability was caused by approximately $1 \%$ unpaired bases in double-stranded DNA. In homologous controls with both labeled DNA and unlabeled DNA from E. ictaluri, the average levels of DNA duplex formation were $66 \%$ in $50^{\circ} \mathrm{C}$ reactions and $73 \%$ in $75^{\circ} \mathrm{C}$ reactions. These values were arbitrarily defined as $100 \%$. Each heterologous reaction was performed twice at $60^{\circ} \mathrm{C}$ and twice at $75^{\circ} \mathrm{C}$. Control reactions in which labeled DNA was incubated in the absence of unlabeled DNA showed an average of $5 \%$ binding of hydroxyapatite. These control values were subtracted from heterologous binding values before normalization.

The relatedness of the ESC bacterium to species of Enterobacteriaceae is shown in Table 4. This bacterium is most closely related to $E$. tarda (56 to $62 \%$ in $60^{\circ} \mathrm{C}$ reactions). In these reactions the percent divergence was 12 to $14.5 \%$, and relatedness fell to about $30 \%$ in $75^{\circ} \mathrm{C}$ reactions, leaving no doubt that the ESC bacterium and $E$. tarda are separate species. The relatedness of the ESC bacterium to species of Esche. richia, Shigella, Salmonella, Klebsiella, Enter. obacter, Erwinia, Serratia, Hafnia, and Morganella (Proteus morganii) was generally between 25 and 35\%, and its relatedness to Proteus and Providencia species was 6 to $11 \%$.

These DNA relatedness data and the biochemical characteristics of the ESC bacterium are consistent with placing this organism in the family Enterobacteriaceae as a new species. The ESC bacterium is phenotypically and genetically most closely related to $E$. tarda. Therefore, we propose the name Edwardsiella ictalurisp. nov. (ic ta lu'ri. M.L. masc.n. Ictalurus generic name of the host catfish; M.L. gen.n. ictaluri of Ictalurus) for the ESC bacterium. The type strain of E. ictaluri is GA $77-52$ (=CDC 1976-78 =ATCC 33202).

A comparison between $E$. ictaluri and "Paracolobactrum anguillimortiferum" (not on the Approved Lists of Bacterial Names [14]) was not possible due to the lack of viable strains of the latter. The data reported by Wakabayashi and Egusa (15) indicate that " $P$. anguillimortiferum" may be more closely related to $E$. tarda than to $E$. ictaluri.

\section{ACKNOWLEDGMENTS}

This research was supported by the Southeastern Cooperative Fish Disease Project, by grant S-83 (ALA-00340) from the Southern Regional Cooperative Research Project, and by grant PL88-309, 2-271-R from the National Marine Fisheries Service.

\section{REPRINT REQUESTS}

Address reprint requests to: Dr. J. A. Plumb, Department of Fisheries and Allied Aquacultures, Auburn University, Auburn, AL 36849 .

\section{LITERATURE CITED}

1. American Fisheries Society, Fish Health Section. 1975. Suggested procedures for the detection and identification of certain infectious diseases of fishes. U.S. Fish and Wildlife Services, Washington, D.C.

2. Barry, A. L. 1976. The antimicrobic susceptibility tests: principles and practices. Lea and Febiger, Philadelphia.

3. Brenner, D. J., J. J. Farmer III, G. R. Fanning, A. G. Steigerwalt, P. Klykken, H. G. Wathen, F. W. Hickman, and W. H. Ewing. 1978. Deoxyribonucleic acid relatedness of Proteus and Providencia species. Int. J. Syst. Bacteriol. 28:269-282.

4. Buchanan, R. E., and N. E. Gibbons (ed.). 1974. Bergey's manual of determinative bacteriology, 8 th ed. The Williams \& Wilkins Co., Baltimore.

5. Bullock, G. L., D. A. Conroy, and S. F. Snieszko. 1970. Diseases of fishes, book 2A. Bacterial diseases of fishes. TFH Publications, Jersey City, N.J.

6. Edwards, P. R., and W. H. Ewing. 1972. Identification of Enterobacteriaceae, 3rd ed. Burgess Publishing Co., Minneapolis.

7. Ewing, W. H., A. C. McWhorter, M. R. Escobar, and A. H. Lubin. 1965. Edwardsiella, a new genus of Enterobacteriaceae based on a new species, E. tarda. Int. Bull. Bacteriol. Nomencl. Taxon. 15:33-38.

8. Ewing, W. H., A. J. Ross, D. J. Brenner, and G. R. Fanning. 1978. Yersinia ruckeri sp. nov., the redmouth (RM) bacterium. Int. J. Syst. Bacteriol. 28:37-44.

9. Hawke, J. P. 1979. A bacterium associated with disease of pond cultured channel catfish, Ictalurus punctatus. J. Fish. Res. Board Can. 36:1508-1512.

10. Hickman, F. W., and J. J. Farmer III. 1978. Salmonella typhi: identification antibiograms, serology, and bacteriophage typing. Am. J. Med. Technol. 44:1149-1159.

11. Meyer, F. P., and G. L. Bullock. 1973. Edwardsiella tarda, a new pathogen of channel catfish (Ictalurus punctatus). Appl. Microbiol. 25:155-156.

12. Ross, A. J., R. R. Rucker, and W. H. Ewing. 1966. Description of a bacterium associated with redmouth disease of rainbow trout (Salmo gairdneri). Can. J. Microbiol. 12:763-770.

13. Sakazaki, R. 1965. A proposed group of the family Enterobacteriaceae, the Asakusa group. Int. Bull. Bacteriol. Nomencl. Taxon. 15:45-48.

14. Skerman, V. B. D., V. McGowan, and P. H. A. Sneath (ed.). 1980. Approved lists of bacterial names. Int. J. Syst. Bacteriol. 30:225-420.

15. Wakabayashi, H., and S. Egusa. 1973. Edwardsiella tarda (Paracolobactrum anguillimortiferum) associated with pond cultured eel disease. Bull. Jpn. Soc. Sci. Fish. 39:931-936.

16. Walters, G. R., and J. A. Plumb. 1978. Modified oxidation/fermentation medium for use in identification of bacterial fish pathogens. J. Fish. Res. Board Can. 35: 1629-1630. 